\title{
Demand Responsive and Energy Efficient Control Technologies and Strategies in Commercial Buildings
}

\author{
Sila Kiliccote \\ Mary Ann Piette \\ Lawrence Berkeley National Laboratory \\ DOE Project Manager: David Hansen
}

September 2006

LBNL Report Number 60784 


\section{DISCLAIMER}

This document was prepared as an account of work sponsored by the United States Government. While this document is believed to contain correct information, neither the United States Government nor any agency thereof, nor The Regents of the University of California, nor any of their employees, makes any warranty, express or implied, or assumes any legal responsibility for the accuracy, completeness, or usefulness of any information, apparatus, product, or process disclosed, or represents that its use would not infringe privately owned rights. Reference herein to any specific commercial product, process, or service by its trade name, trademark, manufacturer, or otherwise, does not necessarily constitute or imply its endorsement, recommendation, or favoring by the United States Government or any agency thereof, or The Regents of the University of California. The views and opinions of authors expressed herein do not necessarily state or reflect those of the United States Government or any agency thereof, or The Regents of the University of California.

This report was prepared as a result of work sponsored by the California Energy Commission (Commission). It does not necessarily represent the views of the Commission, its employees, contractors, and subcontractors make no warranty, express or implied, and assume no legal liability for the information in this report; nor does any party represent that the use of this information will not infringe upon privately owned rights. This report has not been approved or disapproved by the Commission nor has the Commission passed upon the accuracy or adequacy of the information in this report. 


\section{Table of Contents}

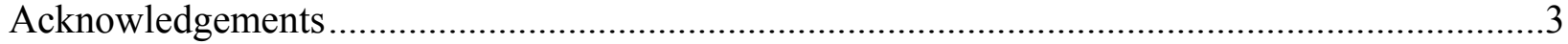

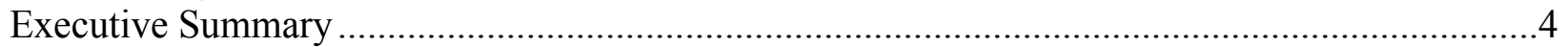

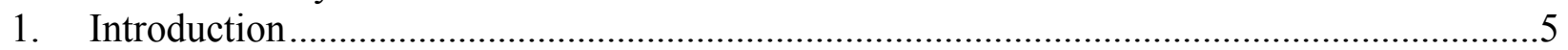

2. What is the Size of Commercial Buildings' Contribution to Peak Demand? ...........................5

3. Can Advanced Building Controls Support Energy Efficiency and Demand Response?.........7

3.1. Demand Response in Commercial Buildings ……......................................................

3.2. Advanced Controls for Demand Response:.............................................................

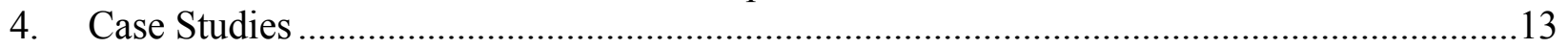

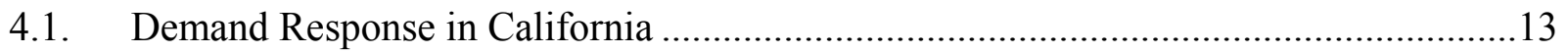

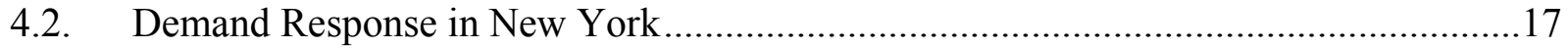

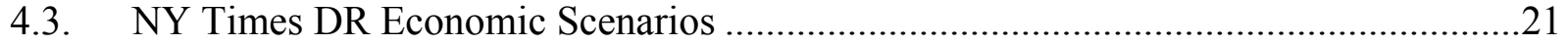

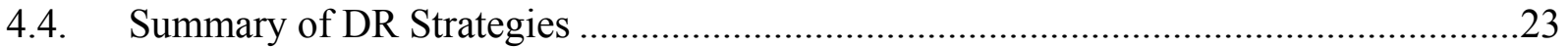

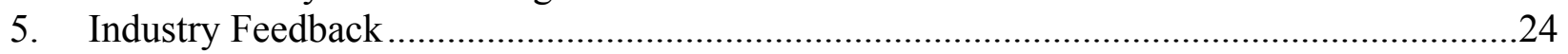

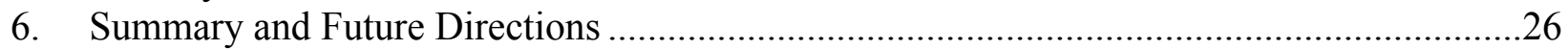

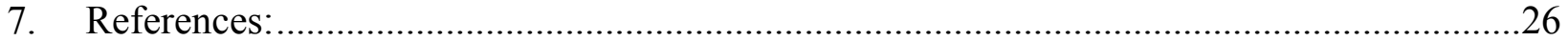

\section{List of Figures}

Figure 1. Demand Profile of Various Demand Response Strategies........................................... 9

Figure 2. Number of Utilities in Each State Offering a Voluntary RTP Tariff in 2003 [9] ......... 10

Figure 3. Distribution of EMCS in Commercial Building by Floor Area in the U.S. .................. 11

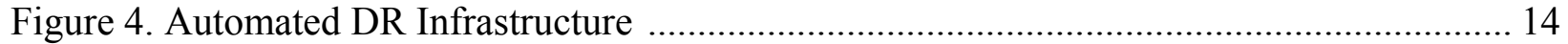

Figure 5. Aggregated Shed for Five Sites on September 8, 2004 .............................................. 16

Figure 6. Demand Shedding Effect of Global Set Point Adjustment ....................................... 17

Figure 7 The New York Times Tower Floor Plan (Source: NaturalWorks) ................................ 19

Figure 8 Preliminary Total Demand Profile of the NY Times Occupied Tower Floors (Source:

NaturalWorks simulations) ……………………...................................................... 20

Figure 9 Strategies Implemented in California and New York Case Study Sites ........................ 24

\section{List of Tables}

Table 1. Comparison of CBECS and NEMS Based Estimates of ................................................ 6

Table 2. Energy Efficiency, Daily Load Management and Demand Response................................ 8

Table 3. Characterization of EMCS in Commercial Buildings in the U.S. ................................. 12

Table 4. Average and Maximum Demand Savings Results from Three Years of Research ........ 17

Table 5. Summary of DR Programs Offered by the Utility Company ......................................... 21

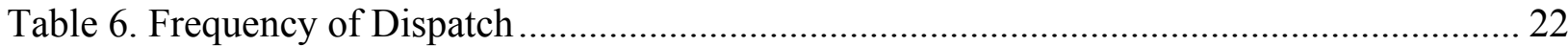

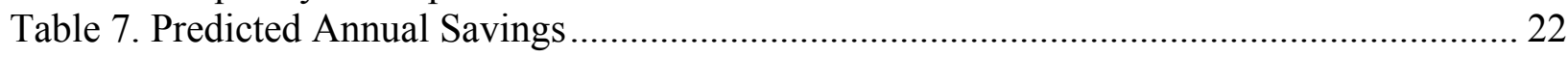

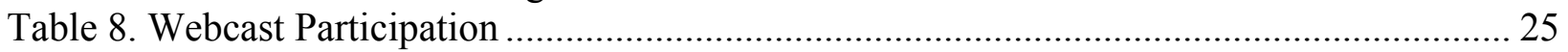




\section{ACKNOWLEDGEMENTS}

The authors thank David Hansen for his support of this work; Chris Marnay and Kristina Hamachi LaCommare for their support in the National Energy Modeling Systems (NEMS) runs; Glenn Hughes, Galen Barbose and Ron Hofmann for their comments; Karen Herter, Eric Masanet, Steve Gable and Kathy Loftus for their review of this report. Research funding was provided by the New York State Energy and Research Development Authority (NYSERDA) and the Demand Response Research Center (drrc.lbl.gov) funded by the California Energy Commission, Public Interest Energy Research Program, under Work for Others Contract No.15099-003, Am \#1 and by the U.S. Department of Energy under Contract No. DE-AC02$05 \mathrm{CH} 11231$. 


\section{EXECUTIVE SUMMARY}

Commercial buildings account for a large portion of summer peak electric demand. Research results show that there is significant potential to reduce peak demand in commercial buildings through advanced control technologies and strategies. However, a better understanding of commercial buildings' contribution to peak demand and the use of energy management and control systems is required to develop this demand response resource to its full potential.

The main objectives of the study were:

1. To evaluate the size of contributions of peak demand commercial buildings in the U.S.;

2. To understand how commercial building control systems support energy efficiency and DR; and

3. To disseminate the results to the building owners, facility managers and building controls industry.

In order to estimate the commercial buildings' contribution to peak demand, two sources of data are used: 1) Commercial Building Energy Consumption Survey (CBECS) and 2) National Energy Modeling System (NEMS). These two sources indicate that commercial buildings noncoincidental peak demand is about $330 \mathrm{GW}$. The project then focused on technologies and strategies that deliver energy efficiency and also target $5-10 \%$ of this peak. Based on a building operations perspective, a demand-side management framework with three main features: (1) daily energy efficiency, (2) daily peak load management and (3) dynamic, event-driven DR are outlined. A general description of DR, its benefits, and nationwide DR potential in commercial buildings are presented. Case studies involving these technologies and strategies are described. The findings of this project are shared with building owners, building controls industry, researchers and government entities through a webcast and their input is requested. Their input is presented in the appendix section of this report. 


\section{Introduction}

The blackouts in California and the Northeast and terrorist threats nationwide caused new concerns about reliable supplies of affordable energy. In New York and California, blackouts caused billions of dollars of losses to businesses and individuals [1,2]. While reliable power is an important goal, economic factors and market issues are key constraints in electricity systems. Recent improvements in developing and demonstrating demand response (DR) in electricity markets begin to address these challenges. Two primary goals of DR are to ensure electric reliability and reduce system costs. DR includes actions to reduce load when contingencies such as emergencies and congestion occur that threaten system reliability or when market conditions raise supply costs. A Federal Energy Regulatory Commission (FERC)-commissioned study reported that a moderate amount of demand response could save about $\$ 7.5$ billion annually by 2010 [3]. The New York Independent System Operator (NYISO) 2002 Emergency Demand Response Program provided $670 \mathrm{MW}$ of load curtailment in a $31-\mathrm{GW}$ power system with reliability benefits estimated at $\$ 1.7$ to $\$ 16.9$ million [4].

Advanced building controls in commercial buildings provide an excellent resource for future electricity DR programs. A recent DOE report to the U.S. Congress on the benefits of demand response provides policy recommendations in six areas. One of these areas is to foster DRenabling technologies like the type described in this report [5]. Recent research on controls includes activities such as the development of whole-building simulations of DR operating strategies in a new advanced office building in New York, and full automation of DR in over 20 buildings in California. This report summarizes the integration of DR in demand-side management activities linking it closely to energy efficiency and peak load management. This approach requires the development of new commercial building control strategies and algorithms, which consider both energy efficiency and demand reduction. Operating strategies and technology investment decisions need to be made based on the relative value of both issues, in the context of the business housed in the building and the specific utility providing the electricity. This report also includes a discussion of the potential for DR savings in commercial buildings. The paper offers a brief summary of DR activities around the U.S. and a description of commercial sector DR case studies.

\section{What is the Size of Commercial Buildings' Contribution to Peak Demand?}

Understanding the magnitude and distribution of electric peak demand in the U.S. is crucial to developing goals and strategies to reduce it. One obstacle to assessing the opportunity for commercial buildings peak load reductions is that there is limited information on the contribution of commercial buildings to electric system peak loads. Two national sources of peak load data are the Energy Information Administration's (EIA) Commercial Buildings Energy Consumption Survey (CBECS) and National Energy Modeling System (NEMS). ${ }^{1}$ CBECS is a national survey of energy-related building characteristics, energy consumption, and expenditures data for

\footnotetext{
${ }^{1}$ See http://www.eia.doe.gov/oiaf/aeo/overview/index.html
} 
commercial buildings. In CBECS, commercial buildings are those that are neither residential (used as a dwelling for one or more households), manufacturing/industrial (used for processing or procurement of goods, merchandise raw materials or food), nor agricultural (used for the production, processing, sale, storage, or housing of agricultural products, including livestock). At least 50 percent of the floor space must be used for purposes other than these for a building to be considered "commercial." The 1995 CBECS data included a unique survey of electric peak demand data. Median peak demand intensity in the entire commercial sector was $5.4 \mathrm{~W} / \mathrm{ft}^{2}$, with office buildings at $6 \mathrm{~W} / \mathrm{ft}^{2}$. Two-thirds of the buildings were summer peaking.

The second source of electric peak demand data, NEMS, is the primary midterm forecasting tool of the EIA. NEMS consists of a group of simulation modules that represent all major energy supply, demand, and conversion sectors of the U.S. economy, as well as general domestic macroeconomic conditions and world oil markets. The commercial sector in the Commercial Demand Module (CDM) of NEMS considers business establishments that are not engaged in industrial or transportation activities as commercial buildings. Its floor space module uses the CBECS floor space as its base with future-year floor space forecasted with new construction trends. Lawrence Berkeley National Laboratory (LBNL) researchers extracted three years of peak demand data (1999, 2003 and 2005) in all sectors within the thirteen regions in the United States from one run that represents the Annual Energy Outlook 2005 (AEO2005) Reference Case.

Table 1 summarizes the comparison of estimates of the maximum summer national peak electric demand from CBECS and NEMS for 1995 and 2003. The CBECS data includes the $25^{\text {th }}$ and $75^{\text {th }}$ percentile information as well as median peak demand density. The CBECS data ${ }^{2}$ have been extrapolated to total coincident demand in two ways: 1) assuming a normal distribution of peak demand power density over the floor space using the $25^{\text {th }}$ and $75^{\text {th }}$ percentile values available from the data set and 2) using the median peak demand density multiplied by the corresponding floor space associated with the same year.

Table 1. Comparison of CBECS and NEMS Based Estimates of Commercial-sector Electric Peak Demand

\begin{tabular}{|l|c|c|}
\hline & $\begin{array}{c}\mathbf{1 9 9 5} \\
\text { (GW) }\end{array}$ & $\begin{array}{c}\mathbf{2 0 0 3} \\
\text { (GW) }\end{array}$ \\
\hline CBECS Estimation 1 & 273 & 333 \\
\hline CBECS Estimation 2 & 317 & 387 \\
\hline NEMS Coincident Peak & 291 & 328 \\
\hline NEMS Non-coincident Peak & 317 & 349 \\
\hline
\end{tabular}

According to the 2003 NEMS data extracted from AEO2005 reference case, while the ratio of commercial building total energy consumption to U.S. total is $35 \%$, commercial buildings account for $45 \%$ of the average system-wide summer coincident-demand peak of $740 \mathrm{GW}$ [6]. Twelve of the 13 NEMS regions are summer peaking, the exception being Region 11, which covers the Pacific Northwest.

\footnotetext{
${ }^{2}$ See http://www.eia.doe.gov/emeu/cbecs/public_use.html
} 
The CBECS and NEMS data suggest that the maximum electric peak demand from the commercial sector is about $330 \mathrm{GW}$ nationwide. Further research is needed to refine this estimate. There are significant discrepancies between regional results from NEMS and state data. The California Energy Commission's forecasting model for peak-load data for 2003 estimates the commercial building sector's peak load to be around 19 GW [7]. The NEMS 2005 data suggests that the coincident peak in California is $30 \mathrm{GW}$. It is important to note that the NEMS CNV Region (California-Southern Nevada) is not exactly comparable to California because it excludes some Sierra and northern California areas.

In summary, commercial buildings account for a large portion of summer peak demand, and are perhaps the largest end-use sector. Research results on automated DR further described below show that there is significant potential to reduce peak demands in commercial buildings, offering an important future resource for DR. A better understanding of the capability of existing and potential future sensors and controls are needed to achieve this potential.

\section{Can Advanced Building Controls Support Energy Efficiency and Demand Response?}

\subsection{Demand Response in Commercial Buildings}

Electricity demand varies constantly. At times of low demand, only the lowest marginal cost plants operate, while at peak times, almost all of available power plants run to meet demand. Electricity providers and their customers are concerned with peak demand because of the financial and environmental challenges of providing growing electric system capacity. The value of DR is summarized by the Peak Load Management Alliance [8] as:

- Having impact on the reliability of the electricity system;

- $\quad$ Reducing costs associated with generation, transmission and distribution;

- $\quad$ Creating efficient markets; reducing suppliers' and customers' risk in the market; and

- $\quad$ Reducing environmental impact by reducing or delaying new power plant developments.

The demand-side management (DSM) framework presented in Table 2 provides three major areas for changing electric loads in buildings: energy efficiency (for steady-state load optimization); peak-load management (for daily operations); and demand response (DR) (for event driven dynamic peak load reduction). In this paper, we present the DSM framework from a buildings perspective, concentrating on energy management and control systems (EMCS) based options. In this paper, the terms "load" and "demand" are used interchangeably. 
Table 2. Energy Efficiency, Daily Load Management and Demand Response

\begin{tabular}{|c|l|l|l|}
\hline & \multicolumn{1}{|c|}{$\begin{array}{c}\text { Efficiency and } \\
\text { Conservation } \\
\text { (Daily) }\end{array}$} & \multicolumn{1}{|c|}{$\begin{array}{c}\text { Peak Load } \\
\text { Management } \\
\text { (Daily) }\end{array}$} & \multicolumn{1}{c|}{$\begin{array}{c}\text { Demand Response } \\
\text { (Dynamic / Event } \\
\text { Driven) }\end{array}$} \\
\hline Motivation & $\begin{array}{l}\bullet \text { Limit Environmental Impacts } \\
\bullet \text { Bill Savings } \\
\bullet \text { Reduce need for electric } \\
\text { system capacity additions }\end{array}$ & $\begin{array}{l}\bullet \text { TOU Bill Savings } \\
\bullet \text { Demand Charge Savings } \\
\text { system capacity additions }\end{array}$ & $\begin{array}{l}\bullet \text { Electric system Economic } \\
\text { efficiency } \\
\bullet \text { Reliability } \\
\bullet \text { Emergency Grid Protection }\end{array}$ \\
\hline Design & $\begin{array}{l}\text { Efficient Shell, Equipment \& } \\
\text { Systems }\end{array}$ & Low Power Design & Dynamic Control Capability \\
\hline Operation & Integrated System Operations & $\begin{array}{l}\text { - Demand Limiting } \\
\text { Demand Shifting }\end{array}$ & $\begin{array}{l}\bullet \text { Demand Limiting } \\
\bullet \text { Demand Shifting } \\
\bullet \text { Demand Shedding }\end{array}$ \\
\hline Initiation & \multicolumn{2}{|c|}{ Local } & \multicolumn{1}{c|}{ Remote } \\
\hline
\end{tabular}

Energy Efficiency and Conservation: Energy efficiency can lower energy use to provide the same level of service. Driven by conservation, environmental protection and utility bill savings, energy efficiency measures permanently reduce peak load by reducing overall consumption. In buildings, this is typically done by installing energy-efficient equipment and operating buildings efficiently.

Daily Peak Load Management: Advanced metering technology makes it possible to differentiate electricity usage patterns of buildings on an hourly or sub-hourly basis. Peak load management is motivated by peak demand charges and time-of-use rates. Typical peak load management methods include demand limiting and demand shifting. Demand limiting refers to shedding loads when pre-determined peak demand limits are about to be exceeded. Loads are restored when the demand is sufficiently reduced. This is typically done to flatten the load shape when the predetermined peak is the monthly peak demand. Demand shifting is shifting the loads from peak to off-peak periods. Figure 1 displays the typical demand profile of a commercial building employing these methods.

Demand Response: Demand response refers to the modification of customer electricity usage at times of peak usage in order to help address system reliability, reflect market conditions and pricing, and support infrastructure optimization or deferral. Demand response programs may include dynamic pricing and tariffs, price-responsive demand bidding, contractually obligated and voluntary curtailment, and direct load control or equipment cycling. DR methods such as demand limiting and shifting can be utilized when the economics and reliability issues are predicted and communicated to each site in advance. Demand shedding is dynamic temporary reduction of peak load when dispatched and refers to strategies that can be possibly implemented within a shorter period of response time (also shown in Figure 1). 
Load Shapes for Load Reduciton Terminology

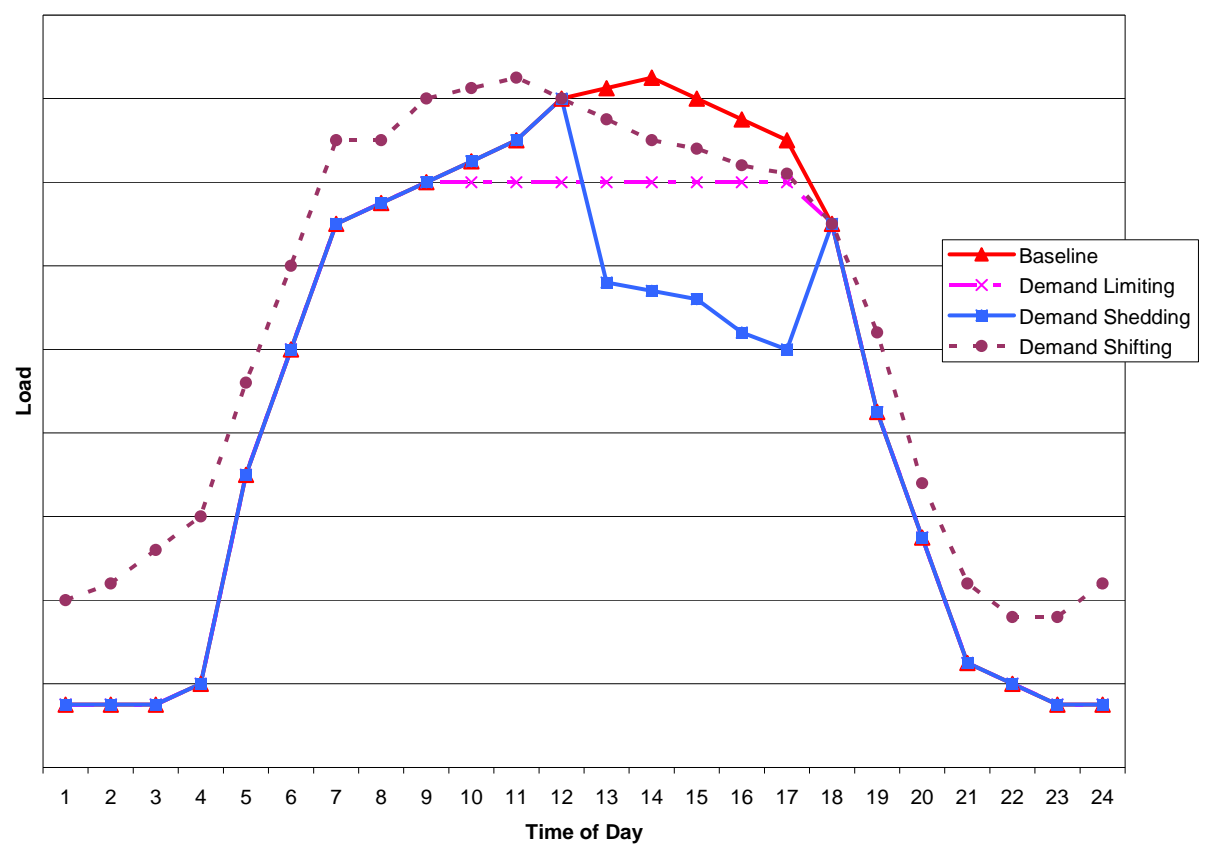

Figure 1. Demand Profile of Various Demand Response Strategies.

Electric utilities in nearly half of all U.S. states are implementing or piloting technology for load management. Load Management is defined by the EIA as any activity other than Direct Load Control and Interruptible Load that limits or shifts peak load from on-peak to off-peak time periods. It includes technologies that primarily shift all or part of a load from one time of day to another and secondarily may have an impact on energy consumption. Examples of systems loads subject to load management include space-heating and water-heating storage systems, cool storage systems, and load-limiting devices in energy management systems. 


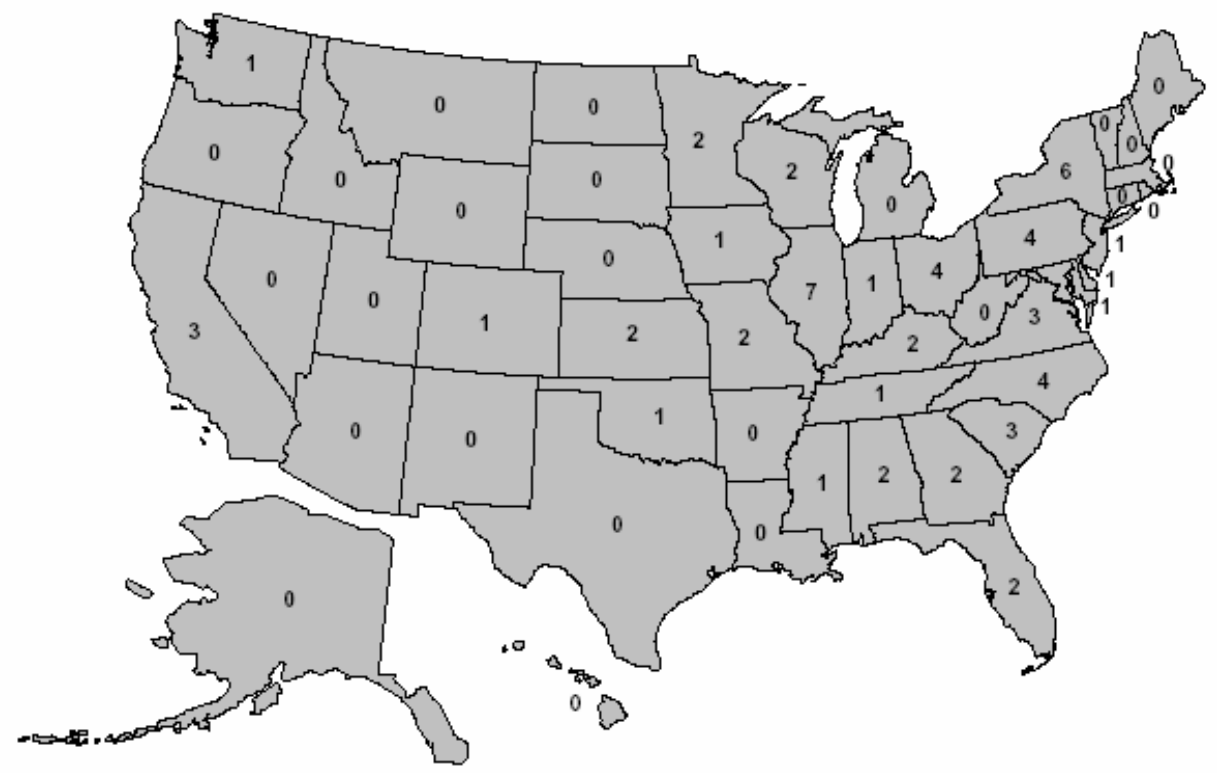

Figure 2. Number of Utilities by State Offering a Voluntary RTP Tariff in 2003 [9]

The daily peak load management also includes programs that aggressively promote time-of-use (TOU) rates and other innovative rates such as real-time pricing. These rates are intended to reduce consumer bills and shift hours of operation of equipment from on-peak to off-peak periods through the application of time-differentiated rates. Figure 2 shows number of utilities in each state offering a voluntary Real Time Pricing (RTP) tariff in 2003. Shorter response times and greater understanding of peak load is required to be truly responsive to any real-time price or reliability related concerns.

\subsection{Advanced Controls for Demand Response:}

Understanding the DR potential in commercial buildings requires examining existing control systems. EMCS in commercial buildings facilitate heating ventilation and air conditioning in buildings (HVAC). Some EMCS provide control of lighting, fire, life support, and safety systems. According to the 2003 CBECS, $7 \%$ of commercial buildings, making up $31 \%$ of the national floor space, have EMCS (Figures $3 a$ and $3 b$ ). Seventy percent of all the commercial buildings with EMCS have at least 50,000 square feet of floor space. Similarly, office buildings and educational facilities show the highest use of EMCS [10]. Day-to-day energy-savings potential of EMCS is estimated to be $10-20 \%$ [11]. EMCS used for DR automation has the potential to reduce peak load by additional $10-15 \%$ as further discussed below. 

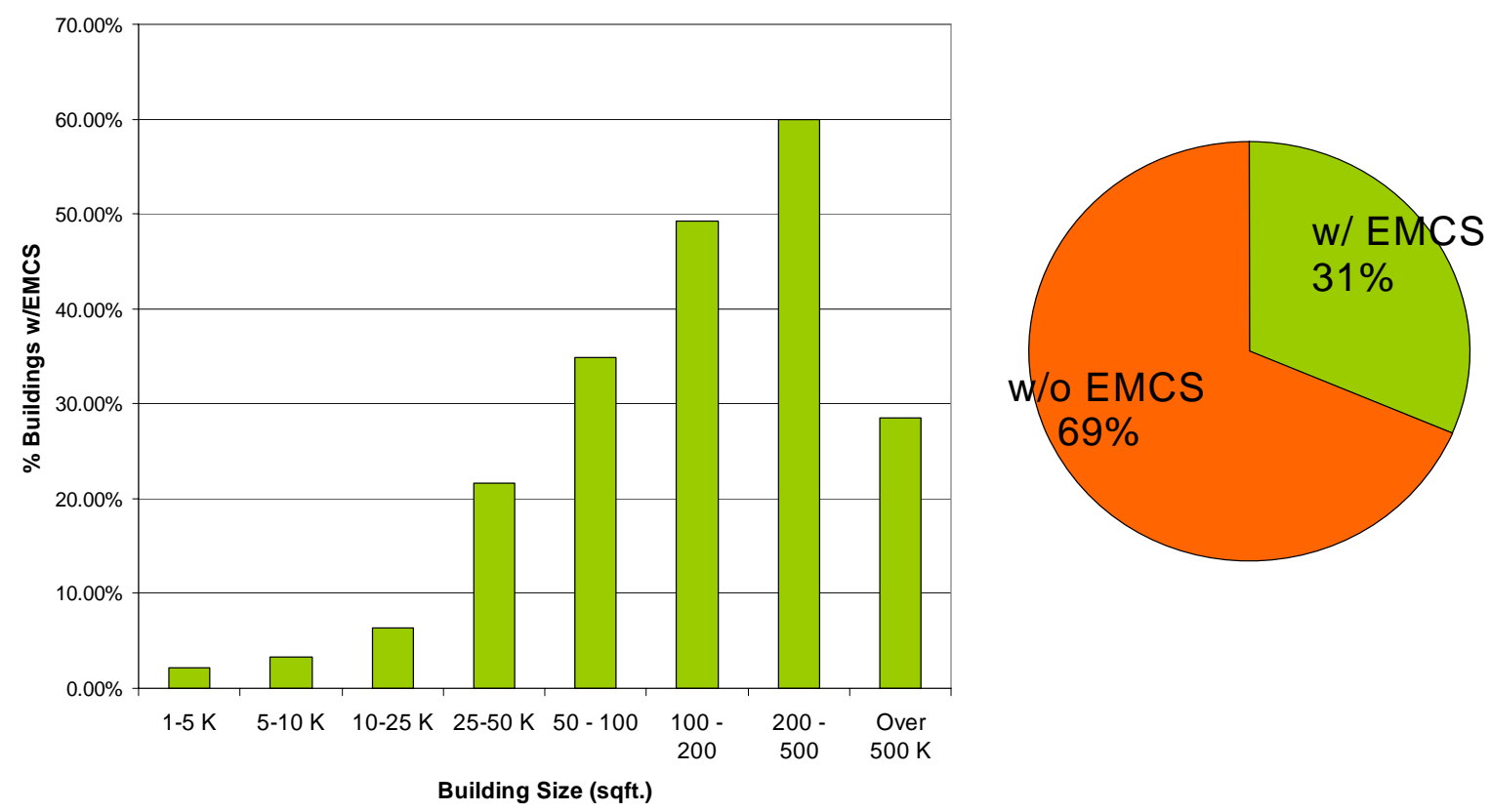

Figure 3. Distribution of EMCS in Commercial Buildings by Floor Area in the U.S.

The buildings in the inventory are categorized as "advanced", "common" and "basic" buildings. "Advanced" buildings refer to newer or larger buildings with sophisticated EMCS. "Common" buildings refer to the average size and age buildings with standard EMCS. "Basic" buildings are older and tend to be smaller in floor space with limited or dated EMCS capabilities.

"Advanced" buildings typically use Direct Digital Controls (DDC). DDC contains networked microprocessor-based controllers that are connected to sensors and actuators. DDC is the most common EMCS technology currently being installed. These systems are scalable and employ precise sensors and accurate controls. DDC is easily integrated or bundled with other building systems with user-friendly interfaces, providing ease of monitoring, maintenance and controls, thereby reducing maintenance and calibration costs. EMCS built upon DDC establish the potential for real-time monitoring of all sensor, control, and data points from a central location. The data can be logged, trended, used for fault detection and as feedback to refine system operation and energy usage. EMCS and DDC implementation enables sophisticated control strategies to maximize operational efficiency and remote connection via Internet. In addition, EMCS functions for DDC-type controls include DR strategy implementation and data analysis tools for energy accounting, making "advanced" buildings the ideal target for DR.

"Common" buildings utilize either pneumatic or electric control infrastructures. Pneumatic systems employ an air compressor that supplies pressurized air through a system of distribution lines to sensors and devices like thermostats, valves, dampers, and actuators to control operations. Pneumatic systems are reliable and the least expensive of the EMCS options. Electric control systems are comprised of controllers, sensors, thermostats, switches, relays, and actuators connected by electrical wiring. However, both systems require preventive maintenance and are hard to modify and expand. EMCS in "common" buildings have limited capabilities, monitoring only selected sensors, collecting limited trend records and providing preset strategies for economizers, variable speed drives (VSDs), and night ventilation. They do not typically collect or provide energy use data. 
"Basic" buildings utilize pneumatic or electrical controls with limited EMCS capability. The EMCS in "basic" building types monitor pre-selected data points and display limited alarms, trends or sometimes energy use data. The control algorithms are based on fixed parameters and modifications to control strategies are hard to implement.

Table 3. Characterization of EMCS in Commercial Buildings in the U.S.

\begin{tabular}{|c|c|c|c|}
\hline \multicolumn{4}{|c|}{ Control Systems } \\
\hline Controls & Basic & Common & Advanced \\
\hline Туре & Pneumatic / Analog & Pneumatic / Analog & DDC \\
\hline \multicolumn{4}{|c|}{ EMCS } \\
\hline Alarms & $\bullet$ & $\bullet$ & $\bullet$ \\
\hline Remote Access & 0 & $\bullet$ & $\bullet$ \\
\hline Operation Information & O & $\bullet$ & $\bullet$ \\
\hline Trend logs & O & O & $\bullet$ \\
\hline Energy Use Info & 0 & 0 & $\bullet$ \\
\hline Real-time monitoring & O & O & $\bullet$ \\
\hline Internet Connection & 0 & 0 & $\bullet$ \\
\hline Control Capability & $\begin{array}{l}\text { Preprogrammed with } \\
\text { fixed parameters }\end{array}$ & $\begin{array}{l}\text { Rudimentary with capability } \\
\text { to implement economizer, } \\
\text { VSD, night ventilation, etc. }{ }^{1}\end{array}$ & $\begin{array}{l}\text { Sophisticated control } \\
\text { algorithms }\end{array}$ \\
\hline
\end{tabular}

${ }^{1}$ Schedules are used to control various HVAC and lighting equipment.

${ }^{2}$ Sophisticated algorithms include optimizing algorithms, demand limiting capability, thermal storage control capability.

The cost of an EMCS depends on the type of building systems and implementation of the associated controls. As the systems diverge from the standard, their costs increase. Simpler systems, with no or little customization options that simply run the building without collecting information for analysis, are least expensive. Innovative systems that require more sophisticated implementation are more expensive, but the additional features allow for more effective and efficient use of the buildings. Therefore, the additional cost of the more advanced EMCS may be justified by reduction in utility bills due to timely fault detection and maintenance, DR savings and labor costs.

Levels of automation in DR can be defined as follows [12]:

- Manual Demand Response involves a potentially labor-intensive approach such as turning off unwanted lights or equipment. 
- Semi-Automated Response involves the use of controls for DR, with a person initiating a pre-programmed DR strategy.

- Fully-Automated Demand Response does not involve human intervention, but is initiated at a facility through receipt of an external communications signal.

EMCS in commercial buildings helps ensure DR participation in two ways: (1) by automating DR events and corresponding DR control strategies, and (2) by integrating new technologies and intelligently processing energy related data to optimize electricity use. In this section, both of these ideas are discussed. Past and current research related to DR automation will be discussed in Section 5. EMCS integration and use for DR will be discussed in detail within the context of the New York Times project in Section 6.

Currently, advanced building controls allow the programming of several modes of operations such as occupied, unoccupied, maintenance, cleaning, night purge, warm up and cool down. These modes are triggered typically by daily or weekly schedules. New technologies and systems, including DR and distributed generation, need to be integrated as a mode of operation within the EMCS. Future buildings will need dynamic control modes triggered not only by a schedule but by information provided to and processed by the EMCS. A master controls concept, where price and reliability information is processed whether the building is on the grid or off the grid, could examine daily operating scenarios between multiple operational criteria. Such criteria might include weather, scheduled building services (occupancy levels), cost minimization, indoor environment quality, and availability of on-site generation or renewable energy sources.

An investment in EMCS to enhance DR capability has the potential to lower the time it takes to respond to a price or reliability driven DR constraint, lower the costs of participation, and increase the frequency of participation. A study conducted by Quantum Consulting states that $10-15 \%$ of the sites that participated in their study could not participate in the DR event because the person in charge of the demand reduction was not in the facility on the day of the event [13]. Enhanced DR capability of a building's EMCS could allow customers to participate in more programs and/or increase revenues from their participation.

\section{Case Studies}

\subsection{Demand Response in California}

California's need for a real-time demand-side infrastructure to respond to supply-side problems led to the establishment of a Demand Response Research Center (DRRC) (drrc.lbl.gov) funded by The California Energy Commission's Public Interest Energy Research (PIER) program and run by Lawrence Berkeley National Laboratory (LBNL). The main objective of the DRRC is to develop, prioritize, conduct, and disseminate multi-institutional research that develops broad knowledge to facilitate DR. The initial projects of the DRRC include: evaluation of real-time pricing for large users, demand shifting with thermal mass and automated DR in commercial facilities. This section concentrates on the automated DR research that has been conducted by the DRRC in the last three years.

The goal of the automated DR is to demonstrate and evaluate the feasibility of automation in large facilities. Hardware and software infrastructure as well as DR strategies for commercial 


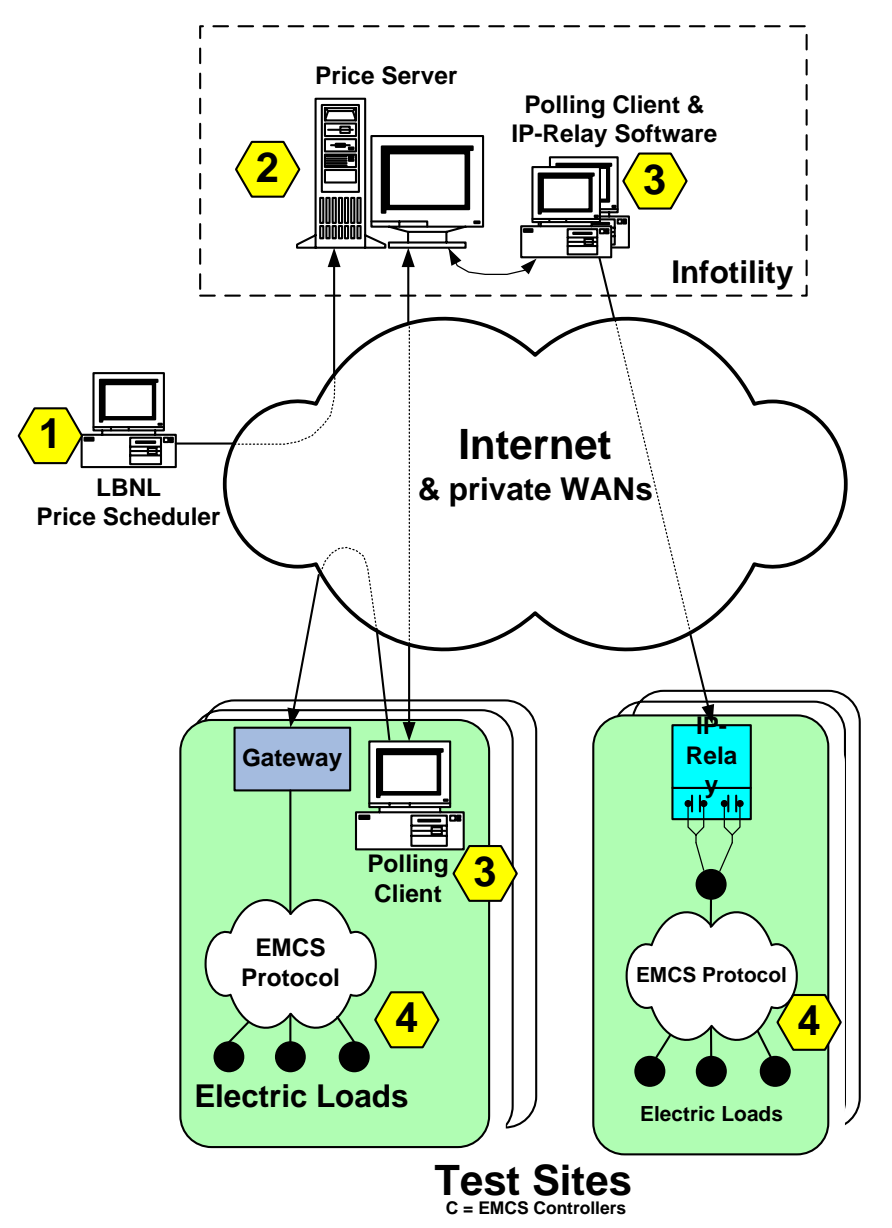

Figure 4. Automated DR Infrastructure [14]

buildings has been the focus of this project. Figure 4 shows the overall sequence of the automated DR network communication.

The sequence of operations in Figure 4 are as follows:

1. LBNL defines the price vs. time schedule and sends it to the price server.

2. Prices are published on the server one day before the event takes place.

3. Clients request the latest price from the server every few minutes.

4. Business logic determines actions based on price.

5. EMCS carries out shed commands based on business logic.

In 2003, one objective of this research was to perform a two-week test of fully-automated DR at four to six facilities. LBNL worked with facility staff to develop a DR strategy that would maximize the electric shed while minimizing any loss of service. The test consisted of continuously providing fictitious electricity price signals to each facility via XML (Extensible Markup Language). Control and communications systems at each site were programmed to check the latest electricity price published by the price server and automatically act upon that signal. Connectivity from the price server to the site was established through Internet gateways 
that enable "Machine-to-Machine" translation. A polling client software enabled each site to pull information from the price server. All of the facilities had Energy Information Systems (EIS) and Energy Management and Control Systems (EMCS) that were programmed to automatically begin shedding demand when the fictitious price rose from $\$ 0.10 / \mathrm{kWh}$ to $\$ 0.30 / \mathrm{kWh}$. The second level price signal increased to $\$ 0.75 / \mathrm{kWh}$. Five sites successfully participated in the test.

In 2004, there were a number of new objectives in the field tests.

1. One objective was to explore new control and communication systems. Both gateway and relay technologies were tested. While the gateway is expensive and requires software development, an Internet relay is a low-cost device that can be actuated remotely over a LAN, WAN or the Internet. The Internet is based on a standard protocol (TCP/IP) and all EMCS can sense the state of relay contact closures (regardless of their particular EMCS protocol). Because of this, Internet relays can be used on virtually any commercial building that has a standard connection to the Internet (i.e., Internet connectivity directly to the EMCS is not required).

2. Another objective was to evaluate the size of the electric shedding potential of the 2003 Phase 1 buildings in warmer weather test events than our schedule permitted in 2003. These buildings participated in a warm weather 2004 "Retest".

3. A third objective was to evaluate how the test could be scaled up to allow more buildings to participate.

4. A fourth objective was to better understand the range of electric shed strategies that are used in large facilities.

All of the 2004 tests were three hour shed events conducted at different times. The facility managers were unaware of the impending DR events.

The communication systems for the 2004 tests differed from the 2003 tests in that new methods of communication were used. During the 2003 test all of the sites had some sort of Web-based EIS and EMCS installed on a PC. During 2004, 5 of the 18 sites used an Internet relay that connected directly to the EMCS control panel. This new method allowed buildings with conventional control systems to participate in the test.

In 2005, with additional funding from Pacific Gas and Electric Company, the research was applied under the Critical Peak Pricing (CPP) tariff. The main objective of this test was to evaluate automation under a specific tariff and consider issues related to the cost of implementation and DR economics of the program as well as researching scaling-up issues regarding the infrastructure. Under the PG\&E tariff, a maximum of $12 \mathrm{CPP}$ days were callable between May $1^{\text {st }}$ and October $31^{\text {st }}$, depending on temperature forecasts. On each CPP day between $12 \mathrm{pm}$ and $3 \mathrm{pm}$, time-of-use rates (TOU) are tripled, and between $3 \mathrm{pm}$ and $6 \mathrm{pm}$ TOU rates are quintupled. On all other non-CPP days during the CPP season, a small credit is applied for each $\mathrm{kWh}$ consumed. Since participation in the study had economic impact for each site, recruitment efforts included signing the sites onto the CPP program, getting interval meters installed, communication tests between the participant and its utility, and the set up of an energy information system by the utility. A total of twelve sites participated in the pilot. Due to growing concerns about security of the network, in addition to the Internet relay and gateway connections, a secure and self-configuring alternative to both was developed. The Client \& Logic with Integrated Relay (CLIR) box connects an EMCS to the price server over the site local area 
network (LAN) and the Internet. The CLIR signals the EMCS through a standard relay contact interface and joins the LAN at commercial building sites without assistance required from the IT administrator. No reconfiguration of the site firewall is required. Predetermined shed strategies are programmed into the EMCS. The EMCS then responds to price- or contingency-based events generated in the price server and communicated via the CLIR Box.

The results of the automated DR research over the last three years described above can be summarized as follows:

- Most building controls and communication technologies are capable of DR automation: The price server infrastructure is designed such that any building with an EMCS and an Internet connection can participate in automated DR [13]. The variety of connections such as the Internet relay, Internet gateway and the CLIR box provide a variety of solutions that can be employed by each site.

- Large sheds without complaints from occupants are feasible: On September $8^{\text {th }}, 2004$, the total demand savings from five automated DR sites reached $1 \mathrm{MW}$ (Figure 5). There were no complaints from any of the occupants in any of these buildings.

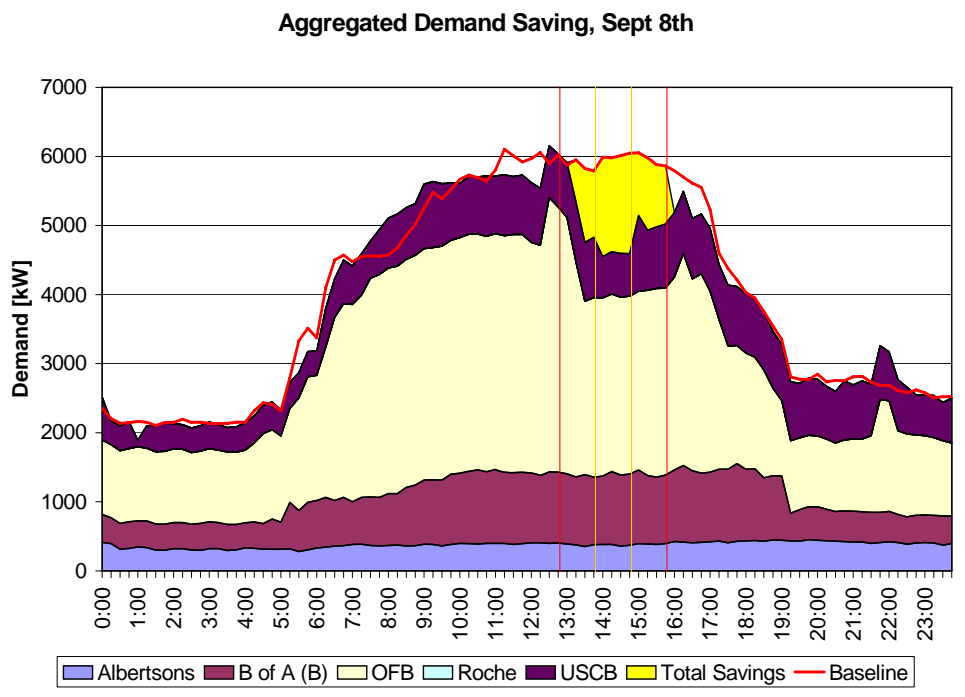

Figure 5. Aggregated Shed for Five Sites on September 8, 2004

- Range of strategies are developed and evaluated for each site to shed loads: Depending on the type of equipment and control system at each site, HVAC and lighting shed strategies were developed. As a result of this work, global set-point adjustment was proposed as a California Energy Standard (Title 24). Global set-point adjustment is the ideal DR strategy for HVAC systems. It is a term used for increasing the cooling set point and decreasing the heating set point. The acceptability of set-point adjustment strategy depends on how much, how fast, how often it is executed and other occupant-related issues such as their layers of clothing, information provided to them, etc. 


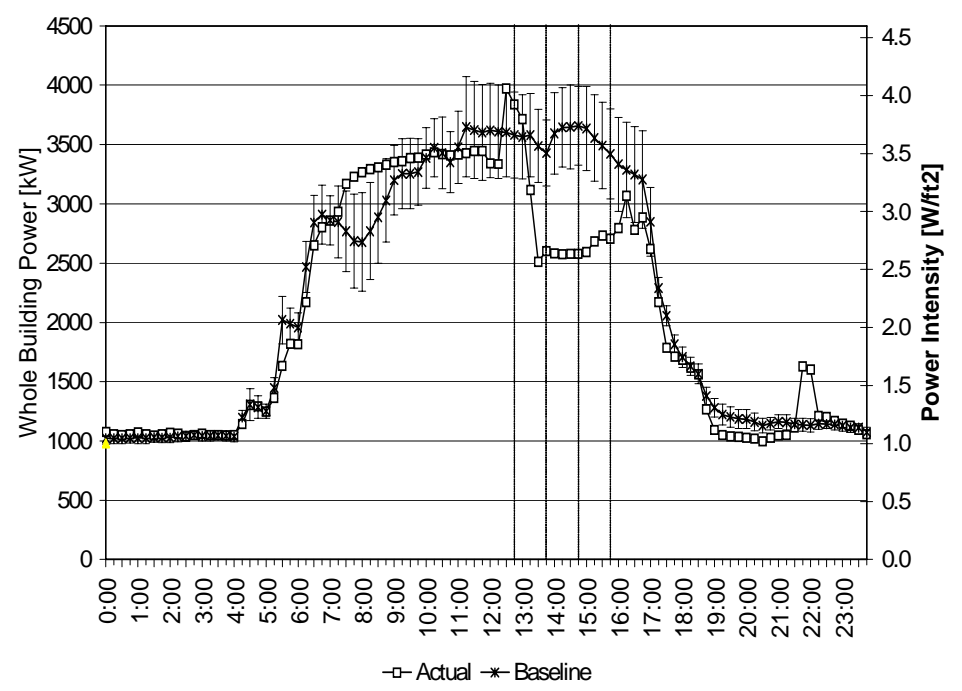

Figure 6. The Demand Shedding Effect of Global Set Point Adjustment

Figure 6 displays the demand-shedding effect of global set-point adjustment in one of the automated DR test sites in California. This large federal facility (about 1 million square feet) reduced its whole-building power by an average of $811 \mathrm{~kW}$ during this 3-hour test by raising the zone temperature set point from 72 to $78 \mathrm{~F}$ [15]. Figure 6 shows whole building power for the shed (the lower curve) and the whole-building baseline power predicted if the shed had not occurred. The vertical line at each baseline-power data point is the standard error of the regression estimate. The baseline load reached $3700 \mathrm{~kW}$, and the demand shed is shown in the lower curve from $1 \mathrm{pm}$ to $4 \mathrm{pm}$. There were no thermal comfort complaints at this test site.

Average of $8 \%$ with a maximum of $56 \%$ demand shedding was achieved. Average demand savings of individual buildings for all the test days and maximum demand savings for the best performing building on one test day for each year is summarized in Table 4.

Table 4. Average and Maximum Demand Savings Results from Three Years of Research

\begin{tabular}{|l|c|c|c|}
\hline $\begin{array}{c}\text { Research } \\
\text { Year }\end{array}$ & $\begin{array}{c}\text { Number } \\
\text { of Sites }\end{array}$ & $\begin{array}{c}\text { Average } \\
\text { Demand } \\
\text { Savings } \\
\text { (\%) }\end{array}$ & $\begin{array}{c}\text { Maximum } \\
\text { Demand } \\
\text { Savings } \\
(\mathbf{\%})\end{array}$ \\
\hline 2003 & 5 & 8 & 28 \\
\hline 2004 & 18 & 7 & 56 \\
\hline 2005 & 12 & 10 & 38 \\
\hline
\end{tabular}

\subsection{Demand Response in New York}

One state that has been a leader in DR is New York. For example, recent research has examined the results of real-time pricing (RTP) in Niagara Mohawk service territory in upstate New York [15]. The default tariff for all large Niagara Mohawk customers (those with over $2 \mathrm{MW}$ of 
service) is an RTP tariff; however, they may change to another service provider. The RTP tariff has successfully provided DR while operating with the reliability-based Emergency Demand Response Program (EDRP) run by the New York Independent System Operator [16].

In New York City, LBNL researchers have been working with the design of the new New York Times (NY Times) headquarters building in Manhattan to integrate lighting and shading devices, commission the lighting systems, and to develop DR strategies and DR controls specifications for the building [17]. The building was designed to promote "transparency" to the public (being a news organization that provides factual information to its customers) via floor-to-ceiling clear glass windows shaded by a unique exterior shading system and combined with interior shades. Enhancing the way employees work was the key objective, with sustainable building design as a secondary objective. Given the constraints of the building's geometry, systems design attention concentrated on energy-efficient building components and systems. The overall intent for interior shades is to keep the shades up as much of the time as is possible without causing thermal or visual discomfort. Thermal comfort is assured by solar tracking and the geometry of the external sun screens. Visual comfort is assured by managing the luminance on the window wall. The specified lighting controls system is a DALI (Digital Addressable Lighting Interface) based system with dimmable fixtures throughout the interior space. This allows the system to dim down the electric lighting in response to daylight levels registered by a luminance sensor located on the ceiling as well as enable dimming of all lighting from a central location via central command. An under-floor air-distribution system is utilized for heating, air conditioning and ventilation of the spaces. This system is supported at the perimeter with fan coil boxes.

The energy simulation study of the NY Times building may be the first in which an hourly model is used to evaluate dynamic DR control strategies during a new construction design process. A custom version based on EnergyPlus (version 1.2.3.023) was written by NaturalWorks and utilized as the simulation engine. Figure 3 is a typical floor plan of a tower floor with zones identified by NaturalWorks for their simulations. These zones are identified with letter combinations that are descriptive of their locations and orientations. For example, ZWLI stands for zone, west, lower, interior. 


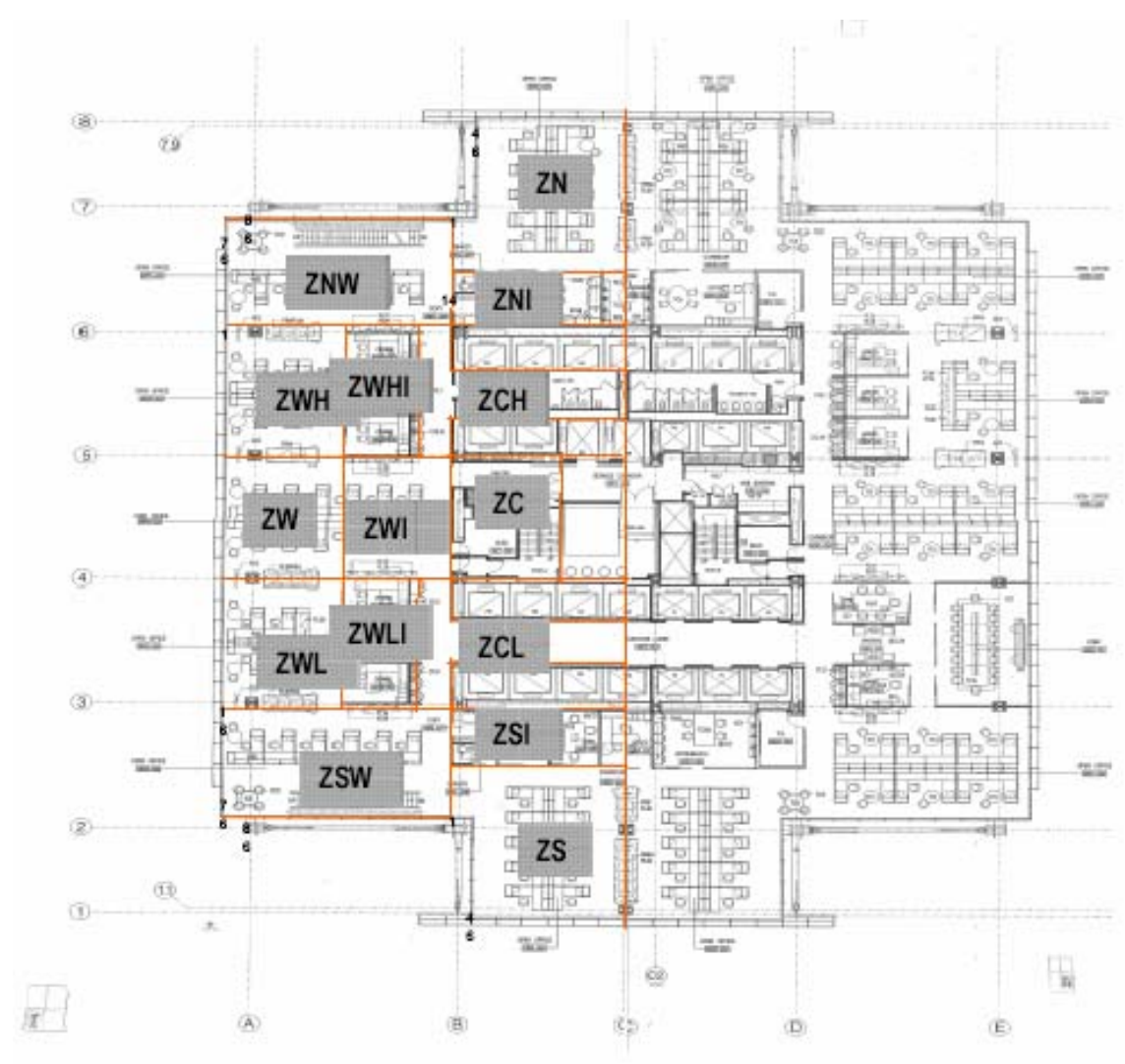

Figure 7. The New York Times Tower Floor Plan (Source: NaturalWorks)

The modeling and simulation effort was conducted by NaturalWorks in two phases that involved several iterations. In the first phase, a basic building model was developed and a limited set of DR strategies were implemented such as shade control and global set-point adjustment. However, the building model was not complete. The owner and LBNL researchers assisted in providing better estimation of values to refine the building model for simulations. During Phase II, NaturalWorks delivered a more complete building model, including the ability to simulate lighting shedding strategies. For lighting management during DR events, the space is divided into three zones considering use and daylight availability: core, interior and perimeter. Two strategies for the lighting system, two levels for temperature set up and two additional HVAC strategies - one increasing the supply air temperature and the other reducing the capacity of fans boxes in the perimeter - were assembled for simulations. DR sequences combining these six DR strategies were simulated by NaturalWorks. 


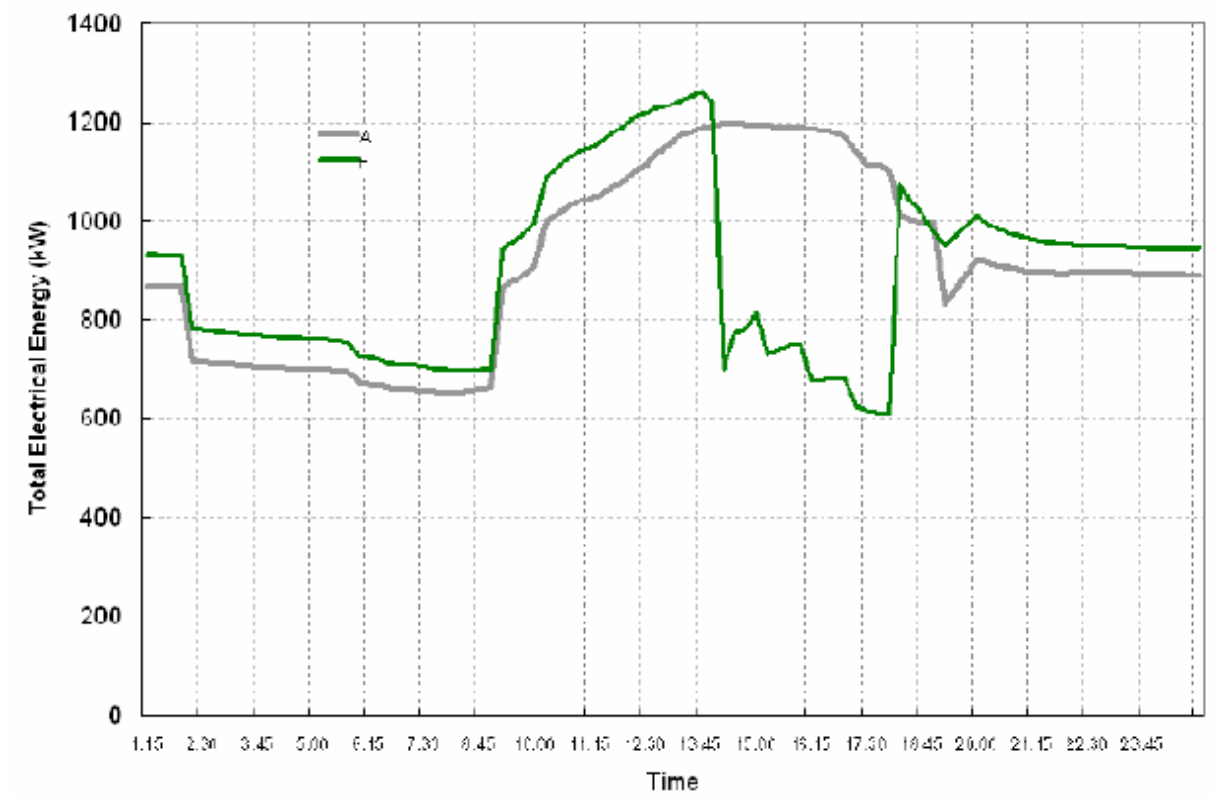

Figure 8. Preliminary Total Demand Profile of the NY Times Occupied Tower Floors

(Source: NaturalWorks simulations)

Figure 8 displays the baseline with overnight pre-cooling and the demand profile of the NY Times building under the best DR sequence. Although the demand savings is shown to be about $600 \mathrm{~kW}$, LBNL chose a more conservative demand savings of $400 \mathrm{~kW}$ for a peak demand reduction on a hot and humid summer day. Occupant comfort under these sequences is still not understood. Therefore, it is recommended that the setpoints are made available to the building operators so that the sequences can be tested and refined during commissioning.

The owner has to decide how aggressive the DR strategies will be implemented. The current simulation results display potential demand savings but do not provide any comfort indicators. NaturalWorks is planning to examine predicted mean vote (PMV) and temperatures in the building in the future that will provide indicators to conditions in the space with various sequences of operations. PMV is a methodology proposed by ASHRAE to evaluate thermal comfort. PMV values range from +3 (hot) to -3 (cold) with neutral at 0 . ASHRAE recommends that the PMV value does not exceed 0.5.

Pre-cooling may improve economic efficiency at the cost of energy efficiency. The energy services company suggested that since pre-cooling increases the morning baseline and the energy is $\$ 0.16 / \mathrm{kWh}$ between 9 am and 11 am and increased to $\$ 0.50 / \mathrm{kWh}$ in the afternoon, any precooling done in the morning affords monetary savings in the afternoon. The pre-cooling strategy developed for the simulation has to be refined. If pre-cooling is to be considered, morning precooling may be as effective and more energy efficient than overnight pre-cooling.

The implementation of DR strategies frequently provides additional energy efficiency and peak load management benefits. This is usually because the person developing the DR strategies has to understand the building systems and operations from a short-term energy and demand savings perspective - a process that can lead to daily savings that otherwise would not have been realized. In the case of the NY Times building, DR simulation findings also resulted in energy-efficiency 
measures. Simulations to determine the position of the shades yielded that the selected internal shading material was causing extra heat gain.

\subsection{NY Times DR Economic Scenarios}

This section summarizes the financial impact of a $400 \mathrm{~kW}$ demand reduction over 4 hours in the NY Times building [16]. Although the simulations identified $600 \mathrm{~kW}$ as potential demand reduction, a more conservative demand reduction of $400 \mathrm{~kW}$ is chosen for the financial analysis because of baseline related issues and simulation assumptions. A reduction of $400 \mathrm{~kW}$ results in a demand reduction intensity of approximately $0.9 \mathrm{~W} / \mathrm{ft}^{2}$.

The amount of financial savings will depend on the financial structure of these programs available from the local utility and the NY Independent System Operator (NYISO). Consolidated Edison offers five DR programs to its customers. Two of these programs are NYISO programs and are exclusive of each other. The DR programs available to the NY Times through Consolidated Edison are summarized in Table 5.

Table 5. Summary of DR Programs Offered by the Utility Company

\begin{tabular}{|c|c|c|c|c|c|c|c|}
\hline Program & $\begin{array}{l}\text { Called } \\
\text { By }\end{array}$ & Notification & $\begin{array}{l}\text { DR } \\
\text { Enrollment } \\
\text { Period }\end{array}$ & Duration & $\begin{array}{l}\text { Required } \\
\text { Shed }\end{array}$ & Baseline & Incentive \\
\hline $\begin{array}{l}\text { Independent } \\
\text { Capacity } \\
\text { Program } \\
\text { (ICAP) }\end{array}$ & NYISO & Day ahead & $\begin{array}{l}\text { Summer } \\
(5 / 1-10 / 31) \\
\text { Winter } \\
(11 / 1-4 / 30)\end{array}$ & $\begin{array}{l}\text { Min } 4 \text { hrs. } \\
\text { (historically } \\
\text { only } 4 \text { hrs.) }\end{array}$ & $\begin{array}{l}\text { At least } \\
100 \mathrm{~kW}\end{array}$ & Yes & $\begin{array}{l}\$ 6.68 / \mathrm{kW} \text { of Unforced } \\
\text { Capacity + energy } \\
\text { payment of no more } \\
\text { than } \$ 0.5 / \mathrm{kWh}\end{array}$ \\
\hline $\begin{array}{l}\text { Emergency } \\
\text { DR Program } \\
\text { (EDRP) }\end{array}$ & NYISO & Min. 2 hr. & $\begin{array}{l}1 \text { year } \\
\text { starting } 10 / 31\end{array}$ & $\begin{array}{l}4 \text { hrs. or } \\
\text { more }\end{array}$ & $\begin{array}{l}\text { At least } \\
100 \mathrm{~kW}\end{array}$ & Yes & $\begin{array}{l}\$ 0.45 / \mathrm{kWh} \text { or } 90 \% \text { of } \\
\text { price of energy in the } \\
\text { real-time wholesale } \\
\text { market }\end{array}$ \\
\hline $\begin{array}{l}\text { Distribution } \\
\text { Load Relief } \\
\text { Program } \\
\text { (DLRP) }\end{array}$ & ConEd & $\begin{array}{l}\text { Min } 30 \\
\text { minutes }\end{array}$ & 1 year & $\begin{array}{l}4 \text { hrs. or } \\
\text { more }\end{array}$ & $\begin{array}{l}\text { At least } \\
50 \mathrm{~kW} \text { for } 4 \\
\text { hrs. }\end{array}$ & Yes & $\begin{array}{l}\$ 0.45 / \mathrm{kWh} \text { or } 90 \% \text { of } \\
\text { price of energy in the } \\
\text { real-time wholesale } \\
\text { market }\end{array}$ \\
\hline $\begin{array}{l}\text { Day-Ahead } \\
\text { Demand } \\
\text { Reduction } \\
\text { Program } \\
\text { (DADRP) }\end{array}$ & NYISO & Day ahead & 1 year & $\begin{array}{l}\text { Depends on } \\
\text { customer's } \\
\text { selection }\end{array}$ & $\begin{array}{l}\text { Depends on } \\
\text { customer's } \\
\text { bid }\end{array}$ & Yes & $\begin{array}{l}\text { Customers are paid at } \\
\text { least the forecasted price } \\
\text { of electricity which will } \\
\text { not be less than } \$ .05 \text { for } \\
\text { each kilowatt-hour } \\
\text { curtailed }\end{array}$ \\
\hline $\begin{array}{l}\text { Voluntary } \\
\text { Real Time } \\
\text { Pricing } \\
\text { Program } \\
\text { (VRTP) }\end{array}$ & Con Ed & Day ahead & 1year & $\begin{array}{l}\text { Not } \\
\text { applicable }\end{array}$ & $\begin{array}{l}\text { No pre- } \\
\text { required } \\
\text { shed }\end{array}$ & No & $\begin{array}{l}\text { Real time prices are the } \\
\text { only } \\
\text { incentive/disincentive } \\
\text { for customers }\end{array}$ \\
\hline
\end{tabular}

New York has had demand response programs for 5 years since the NYISO launched its DR programs in 2001. In recent years, New York State Public Service Commission has been moving towards requiring mandatory real-time pricing which may apply to Consolidated Edison's (ConEd) "Service Classification 4" customers. Since the NY Times will be a ConEd customer under SC4, this regulatory decision directly applies to the NY Times. 
The current motivation for the NY Times to participate in DR is to provide load relief to the electric grid for emergencies and to improve overall reliability. DR control sequences are being created to provide this load relief. If RTP is mandatory, the NY Times may want to consider daily peak-load management and RTP response strategies as well. The current EnergyPlus models can help evaluate PMV and indoor temperatures that provide information for decision making related to occupant health, comfort and satisfaction.

Mandatory RTP: There are five programs offered to ConEd customers summarized in Table 3. Three of these programs are NYISO programs and two are offered by ConEd. If RTP is mandatory, Virtual RTP (VRTP) offered by ConEd and Day Ahead DR Program (DADRP) offered by NYISO will disappear. DADRP is a form of VRTP.

Of the two NYISO programs, ICAP is the more lucrative one because in addition to the demand savings at $\$ 0.50 / \mathrm{kWh}$, it pays a predetermined capacity payment monthly. Last season this was $\$ 6.68 / \mathrm{kW}$ which would result in a $\$ 2600$ monthly payment to the NY Times should the NY Times deliver $400 \mathrm{~kW}$ of demand reduction. In addition, if the NY Times can reduce $400 \mathrm{~kW}$ over $4 \mathrm{hrs}$, it can receive an approximate savings of $\$ 800$ per event. (This program was called once in 2005 for $3 \mathrm{hrs}$. and twice in 2002 for 4 hrs. each). The NY Times can participate in this program every season and needs to deliver the promised amount every time it is dispatched during this period.

Table 6. Frequency of Dispatch

\begin{tabular}{|l|l|l|l|l|}
\hline \multirow{2}{*}{ Program } & \multicolumn{4}{|c|}{ Frequency of Dispatch } \\
\cline { 2 - 5 } & 2005 & 2004 & 2003 & 2002 \\
\hline ICAP & 1 & NA & NA & $\begin{array}{l}2 \text { in summer } \\
1 \text { in winter }\end{array}$ \\
\hline EDRP & 1 & 0 & 2 & 4 \\
\hline DLRP & 9 & NA & NA & NA \\
\hline
\end{tabular}

Table 7. Predicted Annual Savings

\begin{tabular}{|l|c|}
\hline Program & Predicted Annual Savings* \\
\hline ICAP & $\$ 17,632.00$ \\
\hline EDRP & $\$ 1,440.00$ \\
\hline DLRP & $\$ 1,600.00$ \\
\hline
\end{tabular}

* Assuming two dispatches with $400 \mathrm{~kW}$ demand reduction each time.

The other NYISO program, the Emergency DR Program (EDRP), is similar to ICAP but does not pay a monthly fee for the promised savings. Participants are expected, though not obligated, to either reduce electricity consumption or transfer load to an onsite generator for a minimum of four hours. The expected incentive for an EDRP event for $400 \mathrm{~kW}$ demand reduction over 4 hours is $\$ 720$.

These two NYISO programs are mutually exclusive, meaning customers cannot participate in both programs at the same time. In addition, customers participating in ICAP cannot participate in DLRP. 
RTP not Mandatory: If RTP is not mandatory this year, given the afore-mentioned options, ICAP and DADRP participation may be beneficial to the NY Times. The goals of ICAP are similar to the goals of the NY Times, but yield more lucrative savings. In addition, The NY Times may want to participate in the DADRP program to experience RTP at its own pace. DADRP is designed such that the next day's hourly prices are published a day ahead and the customers decide to participate and opt out of the program daily.

Under an RTP scenario, for example with the DADRP, a customer is paid at least the forecasted price of electricity or a minimum of 5 cents for each $\mathrm{kW}$ that is bid and delivered as savings. Using 2005 NYISO's Day-Ahead location-based marginal-pricing system, and assuming a minimum increase of prices over a preset threshold of $\$ 0.25$, the established threshold is exceeded five times during the summer of 2005. Since the limiting factor is the price of electricity, the duration of the shed depends on the duration of the price over the threshold. In 2005 , the total duration of the price over the selected threshold was approximately 36 hours. If the NY Times participated in the DADRP in every hour with a $400 \mathrm{~kW}$ demand reduction, it would save a total of approximately $\$ 7,200$.

\subsection{Summary of DR Strategies}

The collection and organization of case studies nationwide facilitates development of DR strategies. Figure 7 summarizes these strategies with respect to each system and strategies implemented for each system. The data for California sites is compiled from DRRC's automated DR studies. All the strategies are fully automated. Sites were asked to choose and program their own strategies and not to engage in any manual systems adjustments during DR events. The data for the New York sites, with the exception of the NY Times building, is provided by NYSERDA. The strategies at these sites were carried out either semi-automatically or manually.

Out of 32 sites, 18 sites used global set-point adjustment strategy. Although some of these sites combined this strategy with other strategies, seven sites chose to only use global temperature adjustment strategy. Resetting duct static pressure and supply-air temperature are the next commonly used strategies for the HVAC system. On the lighting-system side, most of the strategies concentrate on reducing lighting in areas with little or transient occupancy. Any lighting strategy that involves switching off lights tends to be disruptive and therefore, it is typically carried out in areas where there is minimal disruption to workers. 


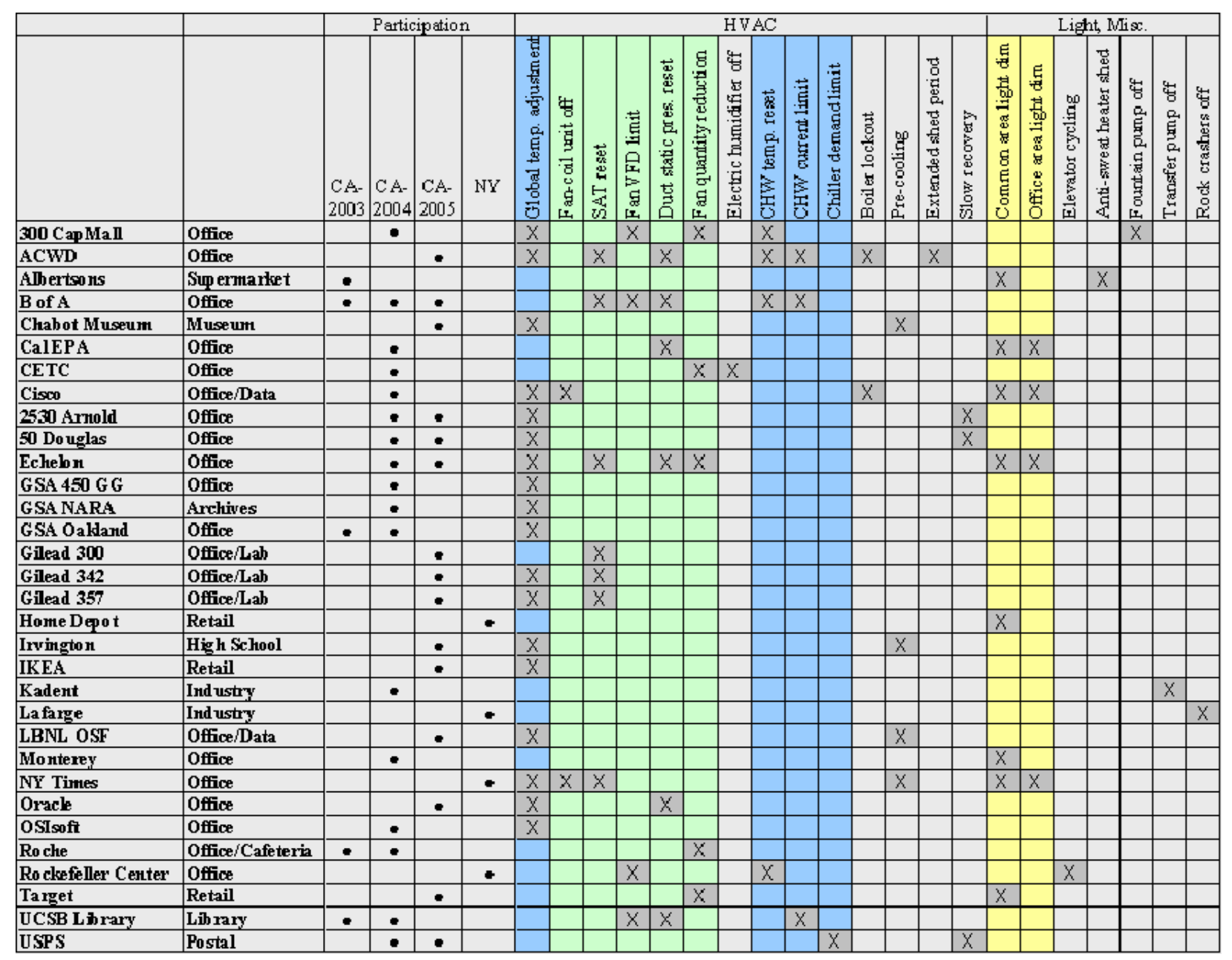

Figure 9. Strategies Implemented in California and New York Case Study Sites

DR strategy work is being further developed to provide a guide to building operators. It concentrates on HVAC and lighting systems with some recommendations for miscellaneous loads. A decision tree for each building system guides the building operators through their DR strategy design. In addition, detailed information on each strategy is provided along with detailed descriptions of the implementation of the strategy and examples of buildings that used the strategies in the past.

\section{Industry Feedback}

As a part of this research effort, we invited building owners, controls industry leaders, researchers, and government agencies to participate in a meeting to discuss the research results. The objectives of the meeting were, to:

- Update building controls companies on DR trends and Automated DR progress,

- Disseminate results of the 2005 studies funded by the U.S. Department of Energy, the California Energy Commission and the New York State Energy Research and Development Authority, and 
- Seek feedback on the advanced DR building controls work to assist in research planning.

LBNL presented the findings outlined in the previous sections of this report in the two-hour meeting. The table below summarizes the affiliation of the participants.

Table 8. Webcast Participation

\begin{tabular}{|l|c|}
\hline Participant Affiliation & Number of Participants \\
\hline State & 2 \\
\hline Government & 2 \\
\hline Control industry & 9 \\
\hline Research & 8 \\
\hline Building owner & 6 \\
\hline Utility & 2 \\
\hline
\end{tabular}

Following the project briefing, a thirty-minute question-and-answer session was held.. While some questions were concerned about building operators' access to information on DR strategies, others concentrated on the DR technologies or programs. Two questions brought up by the control company representatives were: 1) what are the costs of communications technologies, such as an Internet connections and cell phones for a building operators, and 2) what are the costs and benefits of DR implementation. The first question addresses the need for an automation infrastructure: Who will pay for the communication infrastructure development associated with establishing connection with a building? This question will take a few years to answer as the DR community develops standard methods for communications and utilities and ISOs invest in infrastructure. The second issue is also important for the acceptance of DR by building operators and owners. The cost of implementing DR and automated DR, the distribution of the cost over time and floorspace, and the financial benefits (over time and floorspace) associated with program participation all have to be made available for future case-study sites to guide building owners and operators in making DR investments.

Further research needs on demand response and advanced controls are as follows:

- Barriers to widespread DR include regulatory issues and customer acceptance. Benefits of DR versus load shaping programs have to be compared to determine which one better accomplishes what is needed. Development of analysis tools is needed to help customers quantify the expected economic (and other) benefits of DR as applied to their site.

- Fully-automated DR is an important enabler of increased participation for commercial and institutional facilities.

- Further research and analysis of the costs and benefits of implementing DR are needed to determine the commercial viability of the different approaches.

- Further development of building codes to support DR will be useful to determine how and how long normal operations can be compromised. 
- Operators need guidance about strategies for demand response. Therefore, guidebooks, and nationwide case studies are needed.

\section{Summary and Future Directions}

This report has shown that commercial buildings are major drivers in peak electric demands throughout much of the United States. While the commercial sector is a major contributor to peak demands, new research has shown there is significant potential from new and existing controls to provide DR. DR capabilities in buildings revolve around advanced sensors and controls. Field tests show many buildings with EMCS have the potential to reduce peak demands by $5-10 \%$, yet there is limited knowledge on how to develop DR strategies. Further research is needed to evaluate DR control capabilities in the existing stock of buildings considering characteristics such as control vintage, upgrade capabilities, market segments, and new construction trends.

One important aspect of future controls in buildings is that DR capabilities will not be major drivers for new control system. Rather, high performing building controls must require low maintenance that simultaneously supports energy efficiency and healthy indoor environments. Future control systems need to provide improved feedback, continuous diagnostics, and help operators identify and implement low-cost operating scenarios that consider dynamically varying electricity costs and potential on-site generation and renewable energy systems.

\section{References:}

[1] Electric Consumer Research Council (ELCON). "The Economic Impacts of the August 2003 Blackout,", February 2, 2004. Available on line: http:/www.elcon.org/Documents/EconomicImpactsOfAugust2003Blackout.pdf

[2] Lawton, L., M. Sullivan, K. Van Liere, A. Katz, and J. Eto, "A framework and review of customer outage costs: Integration and analysis of electric utility outage cost surveys" (November 1, 2003). Lawrence Berkeley National Laboratory. Paper LBNL-54365. http://repositories.cdlib.org/lbnl/LBNL-54365

[3] U.S. Department of Energy. April 30, 2003. Report to Congress: Impacts of the Federal Energy Regulatory Commission's Proposal for Standard Market Design. DOE/S-0130

[4] Neenan, B., D. Pratt, P. Cappers, J. Doane, J. Anderson, R. Boisvert, C. Goldman, O. Sezgen, G. Barbose, R. Bharvirkar, M. Kintner-Meyer, S. Shankle, and D. Bates. "How and Why Customers Respond to Electricity Price Variability: A Study of NYISO and NYSERDA 2002 PRL Program Performance”. PNNL-14220/LBNL-52209.

[5] U.S. Department of Energy. "Benefits of Demand Response in Electricity Markets and Recommendations for Achieving Them - A report to the U.S. Congress Pursuant to Section 1252 of the Energy Policy Act of 2005." February 2006. 
[6] Hamachi LaCommare, K., December 2005. Personal Communication with Sila Kiliccote: results of NEMS runs for 1995 and 2003, e-mail.

[7] Tian, M., November 4, 2005. Personal Communication with Rich Brown: CEC HELM model annual energy and peak load estimates by end-use. California Energy Commission, e-mail.

[8] Peak Load Management Alliance, "Principles of Regulatory Guidance" February 2002. http://www.peaklma.com/

[9 Barbose, G. and C. Goldman (LBNL) and B. Neenan (Neenan Associates),"A Survey of Utility Experience with Real Time Pricing" LBNL-54238. December

[10] Katipamula S., S. Gaines "Characterization of Building Controls and Energy Efficiency Options Using Commercial Building Energy Consumption Survey" prepared for the Iowa Energy Center, Iowa State University, February 2003, p.24.

[11] Katipamula, S., S. Gaines "Characterization of Building Controls and Energy Efficiency Options Using Commercial Building Energy Consumption Survey" prepared for the Iowa Energy Center, Iowa State University, February 2003, p.52.

[12] Piette, M.A., O. Sezgen, D. S. Watson, N. Motegi, C. Shockman, "Development and Evaluation of Fully Automated Demand Response in Large Facilities" Prepared For California Energy Commission, Public Interest Energy Research (PIER) Program, March 30, 2004. LBNL55085

[13] Quantum Consulting Inc. and Summit Blue Consulting, LLC "Working Group 2 Demand Response Program Evaluation - Program Year 2004 Final Report" p. 5-11, 5-14

[14] Piette, M.A., D. S. Watson, N. Motegi, S. Kiliccote, P. Xu, "Automated Critical Peak Pricing Field Tests: Program Description and Results" Prepared for Pacific Gas and Electric Company Emerging Technologies Program and the California Institute for Energy and the Environment, Draft December 20, 2005.

[15] Goldman, C., N. Hopper and R. Bharvirkar, Lawrence Berkeley National Laboratory; and B. Neenan, R. Boisvert, P. Cappers, D. Pratt, and K. Butkins, Neenan Associates. "Customer Strategies for Responding to Day-Ahead Market Hourly Electricity Pricing" LBNL-57128. August 2005.

[16] Barbose, G., C. Goldman, R. Bharvirkar, N. Hopper, and M. Ting, Lawrence Berkeley National Laboratory; and B. Neenan, Neenan Associates "Real Time Pricing as a Default or Optional Service for C\&I Customers: A Comparative Analysis of Eight Case Studies". LBNL57661. August 2005

[17] Kiliccote, S., M.A. Piette and G. Hughes "Dynamic Controls for Energy Efficiency and Demand Response: Framework Concepts and a New Construction Case Study in New York" Fortcoming Proceedings of ACEEE Summer Study in Energy Efficiency in Buildings August 2006.

National Energy Modeling System (NEMS):

http://www.eia.doe.gov/oiaf/aeo/overview/index.html 
Commercial Building Energy Consumption Survey (CBECS) 1995\& 2003:

http://www.eia.doe.gov/emeu/cbecs/public_use.html 